\title{
The Comparison of Deterrence Punishment for Trade Violations in Ja'fari Jurisprudence and Iran Trade Laws
}

\author{
Abbas Nakhaei ${ }^{1} \&$ Ayat Moulaee ${ }^{2}$ \\ ${ }^{1}$ Postgraduate student of law, general area of study, Islamic Azad University, Sirjan Branch, Iran \\ ${ }^{2}$ Bu-Ali Sina University, Hamedan, Iran \\ Correspondence: Ayat Moulaee, PhD, Assistant Professor in public law, Bu-Ali Sina University, Hamedan, Iran.
}

\author{
Received: September 4, 2016 Accepted: October 2, 2016 Online Published: December 29, 2016 \\ doi:10.5539/jpl.v10n1p114 \\ URL: http://dx.doi.org/10.5539/jpl.v10n1p114
}

\begin{abstract}
Background and objective: In the present study, the comparison of deterrence punishment for trade violations in Ja'fari jurisprudence and Iran trade was examined. Also, the effectiveness of these punishments on reduction of trade violations and the necessity of institutionalizing religious orders in different trades were discussed.

Methodology: the method used in the present study is descriptive-analytical and it used different trade laws and Islamic narrations and Hadith. According to the variety of trade violations in governmental and nongovernmental sectors, seven important violations of hoarding, health violations, business fraud, not to include price, smuggling, use of short weights, and overcharge were discussed in the present study.

According to the main objective of the executives of punishments for trade violators to support and observe consumer rights and also the study of Quranic verses, narrations and Hadith, showed that paying less attention to religious orders has a positive effect on trade violations. Inflation in commodity price and sanction of some consumable commodities has also a positive effect on reduction of trade violations deterrence. The results also showed that the effectiveness of trade violations deterrence is more than its legal resources according to religious and Islamic factors mentioned in Ja'fari jurisprudence. Thus, the necessity of approving a comprehensive trade system law with the approach of institutionalizing the culture of Islam based on trade laws of Ja'fari jurisprudence is felt.
\end{abstract}

Keywords: deterrence, punishment, trade violators, trade laws, Ja'fari jurisprudence

\section{Introduction}

In human societies, observing ethical issues and rights of others, especially the consumer rights are considered as a necessity to prevent chaos and anarchy. However, modifying rules and regulations and increasing punishment is not enough. A systematic and comprehensive solution must be found and the awareness level of people (producer, distributor, importer, and consumer of commodities and services) must be promoted in all directions through different ways. In economic transactions and business of commodities and services to prevent the occurrence of problems and tension between the parties of trade transactions, according to the study of trade transactions in different periods, deterrence punishment of trade violators had different trends. In fact, the more social and closer life and relationships of people increased the transactions and business of commodities. In this regard, the abuse of some people and lack of observing trade laws violated the rights of others and caused chaos and anarchy. Although some special trade laws were modified, the significance of the study of deterrence punishments set in these laws and also their downward and upward trends seem inevitable. It seems that different factors like ignoring religious orders in this area, inflation, sanction, and other factors will affect the deterrence punishments of these violations, thus, in the present study, the effectiveness of these punishments in the reduction of trade violations and also the necessity of institutionalizing religious orders were discussed with the aim of comparing the deterrence punishments set in trade laws with the argument of opinions of Ja'fari scholars by using descriptive-analytical method and different trade laws according to Islamic narrations and Hadith. Since in the current conditions, various trade violations have been studied whether in public sector or non- public sector in the governmental reprimand organization. However, in the present study, the comparison of deterrence trend of important violations such as hoarding, health violations, business fraud, not to include price, smuggling, use of short weights, and overcharge was discussed. 


\section{The History of Addressing Trade Violations}

\subsection{Before the Legislation Era in Iran}

In the early periods of Islam, there were special entities called "Hesba organization" or Audit organization for fighting against corruption and inviting to perform social responsibilities. These simple and extensive administrative entities included some tasks of municipality, police, and prosecution in comparison to today's administrative entities. At that time, sometimes the Muslim Imam became responsible for controlling the audit organization. Audit organization in Iran dates back to the Ghaznavid and Seljuk eras. Particularly, the 5th century AD had a special significance and a Muhtasib or auditor was in charge of audit in every city and big village throughout the lands under their control. The people in charge of the audit were under the control of the commander in chiefs and governors and did their tasks as hard as they could. However, they controlled the market and reported violations like use of short weights, hoarding and overcharge. In the Buyid government, some jobs and resources like auditors were controlled and managed by chief justice. In the Ilkhanid era, when they selected Islam as their religion, the position of auditor still remained as it was. In the Safavid era, every big city had an auditor that did his tasks traditionally with the difference that in that era, the formal religion was Twelver Shi'ism. In general, in the Safavid era, the auditor was in charge of preparing and setting prices in the market and addressing the accounts. Auditors worked with the Sheriff and police chief. After the Safavid era, the tasks and duties of auditors decreased and the responsibility of executing religious orders was taken from them and was given to Marja' (religious references). That part of their duties that dealt with cleaning the cities and addressing the trades was given to the police chief and Sheriff. Thus, the scope of tasks of the duties of auditors was limited to addressing prices, rates and weights. This task was also under the supervision of police chief. In the Zandiyeh era, auditors were in charge of monitoring the prices of markets' commodities and preparing the list of daily prices. Anyway, monitoring the market was always performed from the early periods of Islamic history to the third caliph era. After that, some people worked as an agent and auditor and controlled the markets of Islamic cities. They usually dealt with overcharge, hoarding, use of short weights, business fraud, and etc. This movement developed gradually during the Islamic period and other entities were divided and continued until the Constitutional Revolution (Al sheykhi, 1983).

\subsection{After the Legislation Era in Iran}

Perhaps the root of the first acts and regulations related to trade violations can be found in historical events after the World War II or even during it. At the same time, the status of preparing the needed commodities and provisions of people faced a crisis in Iran. Some jobbers hoarded the essential commodities of people and attempted to gain more profits by creating the black market and selling those commodities with prices higher than their real price. For this reason, for the first time in Article 101 of budget supplement law (supplementary of budget act) approved in 1938, hoarding the monopolies of the government was considered as a crime and legislator set punishments for those who bought those commodities more than their needs and excluded them from the access of the government and consumers. According to this Article, the agents of formal sale or the allowed sellers of the government's monopolies will be profiteer, if they sell the commodities with higher prices. In 1974, according to some chaos in supply and demand process of general needed commodities, the law of setting and distributing the needed commodities of people and punishment of hoarders and profiteers was approved. According to Article 11 of that law, the execution of this law was absolutely devoted to the government and competent courts were military courts. Also, the punishment of execution was predicted for those who caused disruption and instability in the security of the country's general economy. In the Qajar era that is considered as the first period of legislation in Iran an organization called Jalile police department was established that addressed and dealt with trade violations. After that era, some laws were approved to address the trade affairs and order the activities of trade and mainly municipality and city council were their executives. In Aban 1954, the board of ministers approved the regulation of the general assembly of trade and business unions. This regulation was approved to reform and improve trade and business affairs and also the close relationships between merchants and the trades that depended on business affairs, firms, governmental organizations and Tehran municipality. According to this regulation, an entity called the general assembly of trade and business unions was established. Then, according to Article 33 of chamber of commerce laws approved in Dey 7 th, 1954 and administrative regulations it was approved by the ministry of national economy and after completing the regulation of membership in Tehran chamber of commerce and trade unions of merchants in order to run the election of trade unions under the supervision of Tehran's governor. Finally, according to Article 42 of municipal law, the ministry of interior approved a regulation, according to the 16th Article of the above law approved in Tir 1955 entitled as the regulation of trade unions. Some trade violations like hoarding were addressed by a court of justice according to the laws approved in 1937 and 1941 (Bagheri Bid Hendi, 2001). 
In 1971, the first law of trade system was approved. Thus, a trade organization called chamber of trade was created as an independent organization in the country. Since the trade entities needed a valid legal reference after the victory of Islamic revolution, the first trade system after the Islamic revolution was approved by revolutionary command council in Tir 1980. In 1982, the central council of trades was disbanded and two assemblies of trade affairs were established and also an important part of authorities of central trades' council was transferred to the unions. The activities of central council of trades with assembly of the union in Tehran continued until 1989 and in Ordibehesht 1989, the trade system law with some other basic reforms were approved by the Islamic consultative assembly. In the same year, expediency discernment council approved two laws called governmental reprimand law and governmental reprimand law of health affairs and stated that reprimand commission is in charge of addressing violations in the governmental sector and revolutionary courts are in charge of addressing violations in the non-governmental sector. In 1994, the president delegated all reprimand affairs, including governmental and non-governmental sectors to the government, so that the government could use it in the best way according to its role in the constitution to guide the country's economy and control the role of government from supervisor to judge, so that the executive could prosecute and punish the violators of acts approved by the expediency discernment council in governmental reprimand affairs. From 1994 to 2004, for about ten years, the government established two organizations of governmental reprimand and inspection and supervision of prices and distribution of commodities and services respectively under the supervision of the ministry of justice and ministry of commerce with the violations related to trade affairs according to governmental reprimand law and former trade system law. By approving the customer rights protection law in 2009 and according to Article 22 of this law, addressing all trade violations in the jurisdiction of governmental reprimand organization was approved (Ibid).

\section{Trade Violations}

Violation refers to any action or lack of an action that leads to the violation of law or regulations. Accordingly, it can be said that trade violation means the lack of observing specific trade instructions and rules related to different tasks that is done by a group of people that have one job and provides the determined punishments for that action. In other words, a trade violation means the violation of tasks related to social jobs or public services that is done by one of the members while doing the assigned tasks. Some of the important trade violations that deserve punishment are: overcharge, use of short weights, business fraud, hoarding, not to include the price, forced sale, and not to issue a bill.

\subsection{Trade Violations from the Perspective of Governmental Reprimand Organization}

Governmental reprimand, in its literal meaning, is not a new phenomenon. According to the necessity and control of government in economic affairs and the need to collaborate with the references of pricing and commodity distribution, an Article called "reform law of governmental reprimand law" was approved by the expediency discernment council (approved in 1993/11/09). According to this Article, all affairs of governmental reprimand in governmental and non-governmental sectors, including inspection, supervision and issue of a certain sentence, were delegated to the government (executive) in order to work according to the punishments set in governmental reprimand law (Approved in 1989/03/13). The governmental reprimand organization was established with its own tasks under the supervision of the ministry of justice. The competencies of the governmental reprimand branches are limited to the violations of governmental reprimand law and government reprimand law of health affairs and also some cases that were assigned to this organization to be addressed. Thus, all violations of trade system law must be addressed by the branches of this organization. Although there are a lot of discussions on the separation of competencies and qualifications, the emphasis of the organization on observing the law is according to the rules and regulations and far from any development or discriminations. In governmental reprimand law, some predictions and punishments were considered for violations like: 1 . Overcharge. 2. Use of short weights, 3. Business fraud. 4. Hoarding. 5. Off-grid supply. 6. Transportation, maintenance, supply and sale of smuggling commodities. 7. Noncompliance with pricing and distribution rules. 8. Forced sale of commodities and services. 9. Not to include the price and install the price list. 10. Not to issue a bill. 11. Damage and loss to third parties due to trade violations. 12. Not to observe health instructions. 13 . Advertising the commodities, commodities or services contrary to reality. 14. Forced sale of commodities through lottery. 15. Cause damage to legal or natural people with specials or installments. 16. Illegal sale. 17. Trade interference. 18. Hide and avoid the supply of commodities. 19. Not to observe the commitment of importers for receiving governmental currency and services. 20. Not to observe the commitment of producers for receiving governmental currency and services. 21. Not having the operating license of manufacturing units. 22. Currency and Rial sale. 23. Not to announce the inventory. 24. Purchase and release of commodities contrary of the distribution or price rules. 25. Not having the mechanized fund or digital weighing machine. 26. Smuggling a 
variety of oil products. 27. Nonstandard commodities. 28. A variety of trade violations by doctors, pharmacies and hospitals. One of the allocations of governmental reprimand law is observing the degrees of reprimand, i.e. violation in various degrees has different punishments. The punishment of each degree is more severe than the previous degree. Another allocation of this law is the presence of Article 53 and 54. According to these Articles and regardless of the formalities of procedure in public and revolutionary courts in civil affairs, the agent that causes damage will be obliged to compensate for it (Hodvan and Sohrabi, 2011).

\subsection{Trade Violations and Deterrence Punishments}

The dissatisfaction of people with the intensity of overcharge, use of short weights and other trade violations increases every day. Meanwhile, some behaviors not only did not reduce these crimes due to the lack of necessary deterrence, but also promoted a new procedure that most sellers have considered punishments or insignificant crimes against obtaining large profits. Also, a few reprimand treatments never caused the return of extra income of overcharge and vindication of consumer rights and the income obtained from the punishment of these units are returned to the government. Only if there is a private plaintiff, the extra income is returned to him. According to the law, the unions are in charge of monitoring the trade unions but this supervision is light (Bagher Zadeh, 2004).

\section{Punishment of Trade Violators from the Perspective of Ja'fari Jurisprudence and Trade Laws}

To compare the behavior and treatment of jurists and legislators with trade violators and also the punishments considered for violators, it is necessary to explain the concept scope of these violations in Ja'fari jurisprudence, specific trade laws and determined punishments in order to evaluate the deterrence rate of these punishments by matching some parameters like the severity of punishments in legislation resources. Thus, the 7 main violations selected in trade violations, including: 1. Hoarding. 2. Health violations, 3. Business fraud. 4. Not to include the price (pricing). 5. Smuggling. 6. Use of short weights. And 7. Overcharge was analyzed from the two perspectives of Ja'fari jurisprudence and trade laws as follows.

\subsection{From the Perspective of Ja'fari Jurisprudence}

\subsubsection{Hoarding}

Hoarding is one of the obvious examples of violating social rights that has adverse effects and consequences. Such an action is indecent and obscene in terms of reason and religion, but there is disagreement in normative judgment and among Ja'fari jurisprudence. Some jurists, according to the causal credit given in different narrations, consider a respect for hoarding and believe that hoarding must be generalized to all needs of people and some others consider it nasty according to the Taslit rule. According to the jurists, the government can punish such a person in addition to forced sale and pricing the hoarded commodities in case of extortion in price. Some narrations of Ja'fari jurisprudence on the punishment of hoarder were given below:

The prophet (PBUH) said: منه الله برء و الله من برء فقد يوماً اربعين الغلاء به يتربص طعاما جمع من (whoever hoards wheat for 40 days to sell it more expensive, he is not with God and God is not with him)

The prophet (PBUH) said: يكن لم بثنه، فتصدق باعه ثم المسلمين، غلاء به يريد صباحاً اربعين فكسبه طعاماً اشتري رجل أيما لما كفاره

صنع (whoever buys a commodity and keeps it for 40 days to make Muslims pay more money, then sells the hoarded good and gives alms, it will not be the atonement of his action)

The letter of Imam Ali (AS) to Malek Ashtar: البيع وليكن منه، منع آله و عليه الله صلَّ -اله رسول فان الاحتكار من منع فا سمحاً بيعاً

غير فى عاقب و بِه، فَتكل اياه نهيك بعد حكرة قارف فمن المتاع، و البايع من الفريقين با جفَُتُح لا واسعارٍ عدلٍ، بموازين

اسراف (Avoid hoarding because the prophet (PBUH) avoided it). Business must be done easily based on justice, so that neither the seller nor the buyer will lose anything. When you banned hoarding and somebody did it again, you punish him to be a lesson for others).

The prophet (PBUH) said: الله كتاب فى لحد كالم سوقنا فى حتكر (whoever imports something (food to meet the people's need) to our market (Muslims) is like someone who crusades in the way of God (because the Islamic government needs both of them to service) and someone who hoards (the needed food of people) is like someone who is considered as an unbeliever in the holy Quran. Because both groups do not believe in God: one of them does not believe in worship and the other one in God's sustenance.

As was observed in Islamic narrations and Hadith, hoarding is considered very bad by holy legislator, the 14 infallibles and Shiite jurists. The hoarder is considered as a sinner and a punishment was regarded and 
determined for him (Azari Qomi, 1994).

\subsubsection{Health Violations}

Islam has a complete program and plan for human life that includes all his spiritual and material aspects. Environmental health and personal health are among the important aspects of human life. Holy legislator, the infallibles and especially the prophet (PBUH) emphasized the importance of health that was considered as one of the principles of human life. Certainly, the person who does not care about health will not enter the heaven. Thus, observing health orders and instructions that are rooted in beliefs and culture of people affects the reduction of health violations and will have an upward trend in deterrence of health violations; here are some narrations on health:

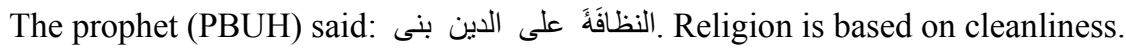

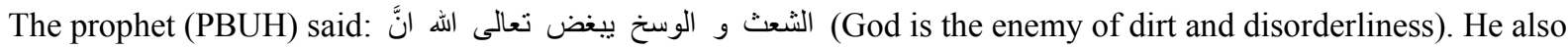
said: النظيف الا الجنه يدخلُ فانه فتنظفو انظيف الاسلام:فرمايد (Islam is clean, then you be clean because nobody will enter the heaven without cleanliness) (Shabestani, 2001).

\subsubsection{Business Fraud}

Fraud includes any planned intentional action that aims to deceive the others and causes loss and damage to many victims, so that the agents earn some benefits. Islam considers special laws for the business and income of people in an Islamic community. These laws are based on legal business and lawful income. Without a doubt, Islam presents the best and most humanistic economic rules and teachings for business and income. On the one hand, these rules and teachings create a human commitment and conscious in people with an emphasis on healthy and lawful business and on the other hand, organize this disorderliness in business and income in the economic system by providing accurate and effective rules based on nature, humanity and justice. Here are some narrations of Ja'fari jurisprudence on business fraud and its punishments:

The prophet (PBUH) said: القيامة يوم الثهداء مع المسلم الصدوق الامين التاجر (a Muslim merchant who is trustee and truthful in his business, will be with martyrs on the last judgment.

He also said: كَرَه ما آو ضَره آو مسلماً غش من منا لبس (someone who cheats on a Muslim in transaction and selling commodities to him and gives him a false commodity or causes damage to him will be not with Muslims.

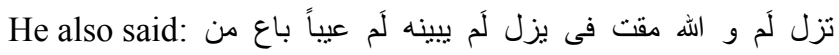

تلعنه الملائكة. (God is always angry at someone who sells a defective commodity without declaring about its defect and angels will curse him forever).

It is observed that if a trade person trades his commodity with honesty and truth, his reward will not be less than martyrs'. On the contrary, if a merchant sells his defective commodity instead of a real one, he will not be a Muslim and his punishment in the last judgment will be like the punishment of unbelievers (Fathi, 2000).

\subsubsection{Not to Include the Price}

It can be inferred from the narrations of pricing (not to include the price) that according to the primary laws and under the normal conditions, the government does not have right in pricing. However, if the seller does not set the price with the aim of hoarding, the government will set the price in order to prevent the extortion of consumer rights. Imam Khomeini said about pricing that: pricing is not allowed at first, however, if the seller overcharges, he should reduce the price otherwise the legislator makes him to sell the commodity with the current price in that country. Thus, the narrations which discuss the non-permissible pricing do not include these examples because keeping the price leads to hoarding. As the seller sets the price in such a way so that nobody can buy it in order to escape from selling the commodity. Without a doubt the legislator has the right to make a decision about it and those narrations do not include this case. Some jurisprudence narrations about this issue are mentioned below (Nuri Yashuluyi, 2008).

Imam Zayn al-Abedin (AS) stated: the prophet (PBUH) was told "we wish you set the price of commodities because the prices have volatility and rise and fall." the prophet (PBUH) said: I do not do something to cause innovation (Bedat) while God does not issue any sentence about it.

و غيره يوجد لَم لَّ و الملح، و الزيت و السمن و الزَّبيب و التَّر و السعر و الحنظه فى الحكره نرك : Maki al-Alemi stated و البيع جب

Avoid hoarding wheat, barley, date, Zante currant, oil, olive and salt, and if these items are not found in someone else, he is obliged to sell them and if he overcharges, the legislator will set the price, otherwise the price will not be set (Maki al Alami, 2006). 
Shahid Thani in the book Masalek that was written to explain the book Sharaye, stated that: unless the case of the owner's extortion that the legislator can set the price, otherwise there is not good and benefit in forced sale because in case of the owner's extortion, if we say that the legislator cannot set the price, the hoarder will be allowed to sell his commodities with a price that cannot be afforded by people, while the intention of forced sale is to remove loss and damage to people.

\subsubsection{Smuggling Commodity}

Since smuggling is one of the emerging issues and was not common in the Anwar Islam Sharia, thus, according to the verses, narrations and jurisprudence opinions of Maraji (Ayatollahs) it was concluded that smuggling does not match to the religious rules and the income obtained from it is not permissible and is unlawful. All the Shiite Maraji (supreme legal authorities) agrees about the prohibition of smuggling commodity. Most jurists prohibited it since the smuggling commodity is contrary to the rules and causes damage to the economy of the Islamic country. For example, only one of the important jurisprudence rules that was given both in the Quranic verses and the unit and was agreed by jurists in many cases is given and its rule of the negation of the way. The sanctity of any action that makes the enemies of Islam or non-Muslims enemies find a way to dominate Muslims is clear according to this rule. Sometimes, the smuggling commodity is accompanied with political motivations on behalf of the enemies of Islam. Even if there are not such motivations, the adverse consequences of smuggling include the decline of economic power and defending the religion. In this case, a way is provided for the enemies of Islam, thus, although the subject of way is not certain in all transactions and businesses, it seems enough to prove the subject of the rule since it provides a context for the guardianship of the unbelievers and domination of the enemies of Islam. Thus, if according to this rule, it is prohibited its accuracy will be not unlikely. Another point that can be mentioned is called the benefit or good intention of Islamic government is related to the conflict of important and the more important. In other words, when two good intentions that are considered and accepted by Islam are placed in front of each other, the good intention of the more important must be preferred and important must be scarified for it. For example, limiting some transactions and import and export in the county that limits the domination of people on their properties, but revives important objectives could be a good example (Nuri Yashuluyi, 2008).

\subsubsection{Use of Short Weights}

One of the damages that threaten lawful business is the use of short weights that is highly blamed on Islam. So that, God has sent down a Surah with such a name and has blamed those who use short weights. The principles of business state that: the believers must put more while weighting and take less while getting their rights. Unlike the famous saying that considered the use of short weights as related to the affairs that can be weighted. This concept has a very broad and extensive scope and includes any loss or depletion in providing services or producing and selling the products including the quality and quantity. Dong less work is also one of the examples of the use of short weights. The Quranic verses consider unity and establishing justice as two main goals for prophets. Social justice cannot be realized without avoiding the use of short weights. The analysis of the effects of the use of short weights, given in the Quranic verses and narrations shows that the use of short weights makes divine mercy go away and causes corruption and destruction in society (Jafari, 2014).

Surah Mutaffifin: Woe to Al-Mutaffifin [those who give less in measure and weight (decrease the rights of others)], Those who, when they have to receive by measure from men, demand full measure, And when they have to give by measure or weight to men, give less than due. Think they not that they will be resurrected (for reckoning), On a Great Day, The Day when (all) mankind will stand before the Lord of the 'Alamin (mankind, jinns and all that exists)?

Surah Al-Rahman: And the heaven, He has raised high, and He has set up the Balance. In order that you may not transgress (due) balance. And observe the weight with equity and do not make the balance deficient.

Surah Al Isra: And give full measure when you measure, and weigh with a balance that is straight. That is good (advantageous) and better in the end.

In this holy Surah that mentioned adultery, manslaughter, and inviolability to the property of the orphan before discussing the subject of accurate measure and weight, the use of short weights was considered among these sins.

Surah Hud: ND to the Madyan (Midian) people their brother Shu'aib said: "O my people! Be servants to Allah, you have no God other than him. Do not give short measure and weight. Surely I see you in prosperity and surely I fear for you the torment of an all-encompassing day". And, O my People! Give full measure and weight in justice! Do not defraud the men their things (rights), and do not act corruptly in the land, making mischief. The remainder of Allah (the profit that the commerce brings, the lawful profit) is better for you if you are believers. 
And I am not a guardian over you.

References to the use of short weights in the Quran prove the obscenity, sin, punishment and otherworldly punishment of the use of short weights and those who use short weights. In verses 7 to 9 Surah Al-Rahman, God compares the importance of observing justice in the accuracy of balance and weight to the importance of justice in the sky. As the previous verses of Surah Al-Isra mentioned the sins of adultery, manslaughter, and inviolability to the property of the orphan, the verse 35 of this Surah considered the disapprobation of the use of short weights as the same as sins.

At Surah Hud, God tells the story of the Midianites and their inappropriate behavior with Shuaib the prophet and their horrible destiny. In verses 84 to 96 of Surah Hud, the holy legislator declared the use of short weights as one of the examples of destruction of the Midianites. The use of short weights was introduced as one of the obvious examples of Haghgholalnas in the holy Quran. The fate of those who use short weights is nothing more than the otherworldly punishment and the fire of the hell that is one of the worst punishments. In verses 1 to 6 Surah Mutaffifin, God warns those who use short weights not to use the short weights because they will stand in front of God on the day of resurrection and will be punished (Holy Quran).

\subsubsection{Overcharge}

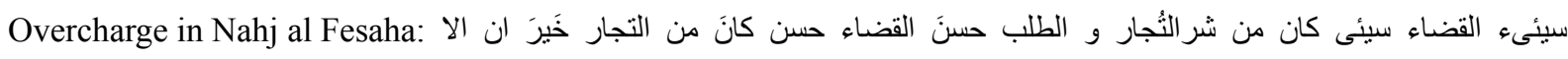

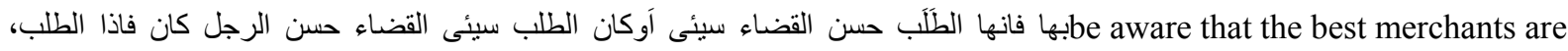
those who give and get well (they give good commodity and get reasonable and fair money). And the worst merchants are those who give and get badly (they give bad commodity and ask for more money). Thus, when a man gives well (gives good commodity) but gets badly (money), or gives badly and gets well (they are considered as merchants).

Overcharge in the holy Quran: Yet had the peoples of the cities believed and been God fearing, we would have opened upon them blessings from heaven and earth; but they cried lies, and so we seized them for what they earned.

Also, People who believe! Do not unjustly devour the property of each other, except through trade by mutual agreement; and do not kill one another; indeed Allah is Most Merciful upon you.

The prophet (PBUH) in Nahj al Fesaha discusses overcharge and introduces the best merchants as those who give good commodity to the customer and get its real and fair price. He also stated that the worst merchants are those who do not give good commodity to the customer and get more money than the real price of the commodity. God in verse 96 of Surah Al- A'raf stated: we And had the people of those townships believed and feared, We would of a surety have opened up to them blessings from the heavens and the earth; but they belied, wherefore We laid hold of them for that which they had been earning (Nahj al fesaha).

The concept of the verse shows that the reason of inflation, expensive commodities and shortage of commodities is the merchants who caused overcharge; use the short weights, hoarding, fraud in bargains and breach of bargains. Also, God in verses 1 to 4 of Surah Al-Humaza, introduces the punishment of the fire hole (hell) for those who illegally earn money through overcharge. In verse 29 of Surah Nisa, God considers the transactions that lack the satisfaction of both parties in material or price as invalid and unlawful. Thus, in transactions that the merchant sells the commodity with more than the real price, the transactions are invalid and unlawful because the buyer is not satisfied.

\subsection{From the Perspective of Trade Laws}

\subsubsection{Hoarding}

After the period of legislation in Iran, especially the law approved in 1938/03/20 and 1942/03/18 about hoarding and trade system law approved in 1980/07/04, the revolutionary command council considered the imprisonment of hoarders in addition to distrainment. In the governmental reprimand law approved by the expediency discernment council in 1989/03/13 and trade system law approved in 2004/03/14 and the reforms made in 2013/09/11, no imprisonment was considered for hoarders. However, according to the repetition of the violation, the fire will increase and deprivation of social rights like closing the trade unit was considered for hoarders. It can be seen that the look and attitude of legislators to the punishment of hoarders was different in every period of legislation according to the conditions governing the society (Shahcheraghi, 2001).

\subsubsection{Health Violations}

Health means the control of factors that endanger the human health. These factors may exist in the work or home environment. Also, there may be some factors in the process of preparation, production, maintenance, 
distribution and sale of foods, drinks, and cosmetics that threaten the human health. In all above cases, all health authorities and legislators make efforts to develop the rules and regulations that control the health of society and guarantee the public health. Now, according to what was said, some rules related to the health violations of trades are mentioned below (Shabestani, 2001).

Note 2 of Article 19 related to the medical and pharmaceutical regulations on foodstuff and beverages approved in 1995/06/19: ministry of health and health department of municipalities are obliged to examine the centers that make or cell medicine, food or drinks and if their materials or containers are not observed by health principles, the seller and buyer will be warned to work according to health principles. In case of violation, the violating health department will be sentenced to punitive imprisonment from 1 to 6 months and the court, according to health department, will order the destruction or distrainment of the commodities (Ibid).

Article 13 of medical and pharmaceutical regulations on foodstuff and beverages approved in 1967/07/13,

Articles 37 and 39 of the governmental reprimand laws for health and medical affairs approved by the expediency discernment council in 1989/03/13.

Article 68 of the trade system law approved in 2004/03/14.

Article 68 of the reforms of trade system law in 2013/09/11.

\subsubsection{Business Fraud}

Different rules and regulations have been developed in Iranian law to support the consumer. The laws that are performed to support the consumer are aimed at encouraging and making the manufacturing and business companies produce high-quality products. The violations of the regulations set in current regulations apply some punishments for the violating trade. The most important rules of this area include:

Article 68 of the trade system law approved by the revolutionary command council in 1980/07/04: the violators of the following rules will be sentenced to pay cash from 500 to 30000 Rials according to the type and importance of the subject. Paragraph 4 of Article 5 related to the law of intensifying punishments for hoarders and profiteers approved in 1988/04/12: the use of inferior materials that brings down the quality of artifacts, products or value of services without devaluation (Example of business fraud).

Article 3 of the governmental reprimand law approved by the expediency discernment council in 1988/04/12: the reprimand of the use of short weights and fraud, according to its amount and degree is exactly similar to the reprimand of overcharge.

Article 11 of the act to demand the rules and regulations of the institute of standards and industrial research of Iran approved in 1993/02/13: whoever changes the properties of the products with compulsory standard after preparation, production or manufacture or uses specific packaging containers of standardized products for packaging, supplying and selling off-standard products, manipulates the can, box, package and cover of the products subject to mandatory standard, supplies or sells another commodity instead of the standardized commodity, uses the test and recognitions papers of products, work permit and Iran standard mark in a wrong place or uses Iran standard mark without receiving a license for his products, will be sentenced to imprisonment from 6 months to 2 years and pay cash from 1 million to 50 million Rials.

Article 59 of the trade system law approved in 2004/03/14 and 2013/09/11 has determined the fire of fraud for its repetition during each year.

With scrutiny in legal Articles in the first trade system law after the Islamic revolution, namely Article 68 of the trade system law approved by the revolutionary command council in 1980/07/04 in the early years of the emergence of inflation phenomenon and sanction of some consumables and according to the current conditions, since the punishment of 500 to 30000 Rials is not enough for those who commit the business fraud, the legislator improved the current gap in the law to intensify the punishment of trade violators by approving the intensify the punishment of hoarders and profiteers and developing paragraph 4 of Article 5. Consequently, by approving and executing the governmental reprimand law in the expediency discernment council in 1989/03/13 especially Article 3 of the law and according to the files investigated on business fraud show an acceptable deterrence. The legislator has considered severe punishments for the increase of business risk in Article 59 of trade system law approved in 2004/03/14 and its reforms in 2013/09/11 (Adib, 2009).

\subsubsection{Not to Include the Price}

According to Article 70 of the trade system law approved by the revolutionary command council in 1980/07/04, the punishment of not to include the price was determined as misdemeanor from 1-60 days to 6 months (trade system law approved by the revolutionary command council in 1980/07/04 with the further reforms). But 
according to Article 6 of the governmental reprimand law approved by the expediency discernment council in 1989/03/13, the punishment of not to include the price in the first time is written warning, including in the unit file, the second time receiving fine from 5000 to 50000 Rials, the third time receiving fine from 50000 to 100000 Rials. And cutting all or some part of state services from 3 to 6 months and in case of interest, installing a fabric as a violator. (A governmental reprimand law approved by the expediency discernment council in 1989/03/13) in Article 65 of the trade system law approved in 2004/03/14, the fine of each time of not to include the price was determined as 200000 Rials that increases every 3 years by the board of ministers according to the inflation rate. (Trade system law approved in 2004/03/14 and reforms in 2013/09/11). Although, the severity of punishment was reduced from early or recent laws in the process of legislation, the punishment of not to include the price in Ja'fari jurisprudence was assigned to the state. If it aims to cause damage to the society, the punishment of hoarding will be considered for it and this type of punishment has more smuggling.

\subsubsection{Smuggling}

In the process of approving the anti-smuggling laws from approving the similar Article of the smugglers punishment law in 1928/03/12 with the latest intention of the legislator, i.e. anti-smuggling laws approved in 2013/12/24 about smuggling commodities. The comparison of early laws to recent laws shows that the attitude of the legislator was towards the decrease of imprisonment and increase of cash punishment that theoretically reduced the risk-taking of smugglers.

The single Article of the smugglers punishment law approved by the national consultative assembly in $1928 / 03 / 12$ states that the smugglers of the money that is the subject of the state income and also those who import prohibited objects to the country, will be sentenced to punitive imprisonment from 8 months to 2 years, loan rejection or the price of the smuggled commodity and prohibited objects.

Article 1 of the smugglers punishment law approved in 1929/03/06: whoever smuggles the commodity that is the subject of the state income or its derivatives (including that the above incomes were explicitly approved according to a special law or the total budget of the country). In addition to loan rejection, he will be sentenced to punitive imprisonment from 3 months to 2 years. Smuggling will be sentenced by the punishment of 3 months to 1 year of punitive imprisonment in addition to distrainment and the half of cash fine.

Articles 2 and 3 of the law governing the application of governmental reprimand about the smuggling of commodities and currency, approved by the expediency discernment council in 1995/05/02 (Vatanpoor, 2008).

\subsubsection{Use of Short Weights}

In Surahs : 1. Mutaffifin, 2. Al-Rahman, 3. Al-Isra, 4. Hud, 5. Ash-shu'ara, 6. Al-an'am, 7. Al- A'raf, the Quran mentioned the use of short weights. According to verse 35 of Surah Al-Isra that was matched to the last verses, the use of short weights was considered as one of the sins (Holy Quran, Surah Al-Isra verse 35) and also the Quran introduced the use of short weights as a cause of destruction of Midian City and its people (Jafari 2014:20). According to Article 58 of the trade system law approved by the Islamic consultative assembly in 2004/03/14, the fire of the use of short weights according to the number of its repetition during each year is to pay a cash fine double the fine for the use of short weights and in the third stage the fine is installing fabric and in the fourth stage is closing the trade unit for 4 months in addition to the doubled fine. According to the narrations and the Hadith of Ja'fari jurisprudence, the punishment of sins is not something more than the fire of the hell, so that the punishment of those who use short weights in Ja'fari jurisprudence is too much more than their punishment in trade laws (Ibid).

\subsubsection{Overcharge}

Without a doubt, coping with any abnormal social phenomenon needs the presence of necessary legal instruments to prevent and deal with it. So that nobody can deal with social abnormalities without the presence of comprehensive and universal laws. One of these abnormalities that is more manifested today is a violation called overcharge that enters the highest pressure to different classes of society especially the lower class of the society. Overcharge of consumables to increase the final price of products is not considered as a violation. But in some cases, producers or suppliers sell the consumables more than the set price in order to gain more money. So this work is a violation and the legislator has set a punishment for the violators. But the principle of determined punishment and fire is not enough, but the law must be executed and the violator must be punished. Most people think that the governmental reprimand organization is in charge of dealing with overcharge and if the overcharge is spread, they consider that it is the organization's fault. However, the study of the legal tasks of this organization shows that the legislator has created some barriers and obstacles in different ways for this organization. These barriers had no result except the impossibility of full and complete fight against economic 
violations including overcharge. The most important rules that are discussed in line with overcharge are:

Article 73 of the trade system law approved by the revolutionary command council in 1980/07/04 with its further reforms: every legal and natural person who sells his products or commodities more expensive than the set price, receives the price of services more than the determined price, apparently trades with a common and set price but receives more money inherently, decreases the properties of products or value of services by using the materials with low-quality, uses short weights or receives more money from the customers will be sentenced to pay cash from 10000 to 500000 Rials or misdemeanor punishment from 6 months to 1 year or both punishments.

Article 5 of the law to intensify the punishment of hoarders and profiteers approved in 1988/04/12: whoever commits one of the following crimes will be sentenced to pay cash from 2 to 5 times for the first time, 5 to 10 times the price of the violated commodities and services for the second time and 10-20 times the price of the violated commodities and services for the third time in case of trade individuals, their license will be canceled in addition to the punishment of the second time.

Article 2 of the governmental reprimand law approved by the expediency discernment council in 1989/03/13: the supply of goods and services with a price more than the prices determined by official authorities as provisional or definitive and the lack of the execution of pricing rules and regulation and taking any other measure that leads to the increase of the price of commodities or services for the customer.

Article 57 of the trade system law approved in 2004/03/14: the supply or sale of products or services with a price more than the prices determined by official authorities as provisional or definitive and the lack of the execution of pricing rules and regulation and taking any other measure that leads to the increase of the price of commodities or services for the customer.

Article 57 of the trade system law approved in 2013/09/03: according to Article 57 of this law, the profiteer will be sentenced to pay 10 times the price of the overcharge and suspension of his trade unit and etc. at the fifth time. This punishment cannot be compared to the punitive of the holy legislator while the punishment rate of trade violators from the perspective of the holy legislator and the infallibles (AS) in Islamic jurisprudence was compared to the punishment determined by the legislator. It was determined that the punishments included in jurisprudence references were more severe and deterrent than the determined punishments in the trade system law.

According to Article 57 of the trade system law approved by the Islamic consultative assembly in 2004/03/14, the fine of profiteers was determined respectively as installing fabric and closing the determined trade unit for 3 months. It is obvious that the punishment included in Ja'fari jurisprudence for overcharge, i.e. the fire hole, cannot be compared to the punishment included in the law. It seems that profiteers could manage their violation procedure well and achieve their goals in the condition of inflation and sanction (Khaleghi).

\section{Conclusion}

In the present study, seven main trade violations, including hoarding, health violations, business fraud, not to include the price, smuggling, use of short weights and overcharge in Ja'fari jurisprudence and Iranian trade laws were discussed and compared. It is obvious that time requirements create new violations.

- In case of hoarding, the narrations and Hadith of Ja'fari jurisprudence believe that hoarding transactions are unlawful. Hoarding can be true in all human needs according to the recognition of the current jurist. By comparing the punishment of a hoarder in jurisprudence references and studying the legislation, it can be concluded that: firstly the deterrence of hoarding from the early years of the research scope of time to the late years of the scope of research in punishments set in Islamic jurisprudence has more deterrence in comparison to the trade system law in Iran. Secondly, the theoretical aspect of violation risk-taking was reduced in the process of legislation from early laws to recent laws by eliminating the imprisonment. Thirdly, the created conditions and inflation after the imposed war of Iraq against Iran had a determining role in hoarding by hoarders.

- In case of health violations, in Islamic narrations and the Hadith, the orders of the holy legislator and the infallibles (AS) on health was considered as one of the important aspects of human life. It is so important that whoever does not care about health and does not observe the principles of health will not enter the heaven where is the final goal of human. From the legal perspective, some punishments like closing, cash fine and etc. could not have more effect on prevention of health violations, thus in health recent laws, less deterrence is inferred.

- By observing jurisprudence narrations and Hadith on business fraud, it becomes obvious that the trade person, who trades his commodity with trust and honesty, will receive an award equal to the person who was martyred in the way of God. On the contrary, the merchant who trades a false commodity will be punished in the last judgment like the unbeliever. Thus, observing the religious orders can have a good effective deterrence. 
Business fraud in legislation, despite the increase of punishments from early laws to recent laws by observing the statistics, the deterrence of business fraud had a downtrend and is not satisfactory.

In case of not to include the price, according to the narrations and the Hadith of jurisprudence references, the state does not have any right in pricing in normal conditions. When the seller does not set the price with the intention of hoarding and damaging the society, the state will set the price in order to prevent loss and damage to the consumer rights. As we move from early laws to recent laws, the risk of violation for those who do not include the price will decrease and the violation of not including the price shows a significant development in time and place scopes of the research. Thus, its deterrence will reduce.

In case of smuggling in Islamic narrations and Hadith, according to the response of Ayatollas about the jurisprudence and religious place of smuggling, the opinion of Ayatollahs about the disapprobation of smuggling is almost equal and they agree on the unlawfulness of smuggling that causes damage to the country. Unlawful actions are considered as sin in jurisprudence references and will end in otherworldly punishment. In case of smuggling in the legislative process of fighting against smuggling and by observing the early laws with recent laws and removing the imprisonment, firstly the risk of smuggling was reduced theoretically, secondly the deterrence punishment of trade violators in smuggling shows a downtrend with the increase of the statistics of smuggling files in the time and place scopes of the research.

In case of the use of short weights, it can be said that it is a violation that has allocated many Quranic verses, so that it was next to the sins like adultery, manslaughter and infringement. Somewhere else, the use of short weights was considered as an obvious example of Haghgholnas. In Iranian laws and from the perspective of a legislator, it is inferred that some degrees of punishment were considered for the person who uses short weights. Firstly, its risk of violation is decreased. Secondly, the deterrence of this violation is commented especially in procedures with the increase of the statistics of addressed files in the time scope of the research. Also, the feedback and the result of the laws that increased the punishment of those who use the short weights are not analyzable in the time scope of the research.

In case of overcharge, the jurisprudence narrations and Hadith show that the reason of inflation, overcharge and shortage of commodities in society is the merchants who overcharge, use the short weights, hoard and commit breach and fraud in their trades. In the Quranic verses, the punishment of those who overcharge was introduced as the fire hole (the hell) and the trades in which the two parties are not satisfied (due to overcharge and etc.) are considered as invalid and unlawful. It seems that the punishment of 10000 to 500000 Rials or misdemeanor imprisonment from 6 months to 1 year for the profiteer had an acceptable deterrence until the phenomenon of sanction and inflation was not tangible and obvious because the legislator approved the law of intensify the punishments of hoarders and profiteers with the beginning of inflation and sanction of some consumables in order to prevent the increasing intensification of overcharge. With the increase and continuity of sanction and inflation, the determined punishments were not enough, so that the legislator reformed the governmental reprimand law to control trade violations, especially overcharge that did not have much effect on the control and deterrence of trade violations and especially overcharge because the reduction of the deterrence of trade laws especially the violation was proved with the increase of the statistics related to overcharge documents and files.

Finally, in case of evaluation of analysis of deterrence punishment, the following results were inferred by matching some parameters like the severity of punishments in the jurisprudence and legislation references:

Firstly, according to the disapprobation of trade violations in Ja'fari jurisprudence references, the deterrence of trade violations in Ja'fari jurisprudence is more than its legal references.

Secondly, the main goal of the legislator was to support the consumer right and vulnerable class of the society. Thirdly, the presence and occurrence of sanction and inflation during the imposed war of Iraq against Iran or after that shows a determining role in the increase of trade violations. It seems that the solution must be found somewhere else. Here, the necessity of approving a comprehensive trade system law with the approach of institutionalizing the culture of Islam, especially on the basis of trade laws in Ja'fari jurisprudence.

\section{Suggestions}

The awareness of trade people to the disapprobation of trade violations in Islamic jurisprudence will have a positive and significant effect on the prevention and reduction of trade violations and deterrence punishment. Thus, it is suggested to comply with some principles of business, according to the practical and ethical charter of businessmen and traders: 
- Muslim businessmen and merchants should collaborate with the appearance of their business activities and match them to the guidelines of the prophetic tradition and make an effort to satisfy God in order to use the worldly interests and enjoy the otherworldly blessings.

- The main capital of Muslim businessmen and merchants is their trust. If people consider a businessman trustworthy, they will consider him trustworthy in the standard and quality, full weight and appropriate price.

- Muslim businessmen and merchants should avoid uncertain situations because whoever enters the uncertain affairs has mixed his lawful properties to unlawful ones.

- Muslim businessmen and merchants should have honesty in their jobs.

- Businessmen should pay attention to others' interest as they think about their interest and income, according to cooperation and a sense of responsibility to others.

- Greed of Muslim merchants to the market and material business should not be more than their greed to queues of congregations. Muslim merchants should avoid swearing in their business even if they swear truly.

- Muslim businessmen and merchants should avoid hyperbolic praise in their business commodities while they pay attention to the value of lawful trades, interest and honesty.

- Muslim businessmen and merchants should install the verses related to business on the door of their shop. Certainly, when the words of God are associated everyday in their minds and thoughts, they will be institutionalized in the minds of merchants and prevent them from probable violations.

- Muslim businessmen should take back the defective commodity. Because God will forgive their sins in the last judgment.

- Muslim businessmen should avoid hoarding. They should not store their commodities to overcharge them later, while people need them badly.

- Muslim businessmen and merchants need to pay Khums and Zakat to purify their properties and keep their properties and capital away from evil.

- In case of need, they should select faithful and honest partners. Muslim businessmen should know that accompanying the faithful and trustworthy partners in business is totally in their favor.

- $\quad$ Avoiding to give and take bribes.

- Contentment and avoiding greed.

- To fulfill the promise and honesty and Muslim businessmen and merchants in promise and avoiding the breach of promise.

- Muslim businessmen should reveal the defect in their commodities and should not hide them.

- Muslim businessmen should be careful about the trust and speech of brokers and dealers.

- $\quad$ They should be the owner of whatever they sell or should have the permission to sell it.

- The commodity that is treated should be clean and permissible and its conditions should be certain to the buyer and the seller should have the power to deliver the commodity.

- Business should be done to the satisfaction of both parties because the base of business and transaction is the satisfaction of both sides.

- The recognition of religious prohibited commodities in the laws of Islam and preventing their business

- Muslim businessmen and merchants should not provide customs smuggled commodities in their business workplace.

\section{References}

Adib, M. (2009). consumer rights. bar association monthly magazine, 52(108), 39.

Al Sheykhi, S. (n.d.). trades in the Abbasid era, translated by Dr. Hadi Alem Zadeh, Tehran: university publication.

Azari Qomi, A. (1994). hoarding and overcharge (1st ed.). velayate Faqih school publication.

Bagher Zadeh, A. (2004). an attitude to trade system law (1st ed.). Tehran, Delavar.

Bagheri Bid Hendi, N. (2001). a look at the biography of famous auditors, second year, No. 5.

Fathi, M. J. (2000, Summer). organizations and entities to figth for economic violations. journal of Qom higher 
eductaiuon complex, 2(6).

Hodvan, M., \& Sohrabi, M. (2011). legal system to address trade violations in governmental reprimand organization (1st ed.). Tehran, Jangal publications.

Holy Quran.

Jafari, Y. (2014). the use of short weights and usury. lessons of Islam school monthly magazine, 54(11).

Khaleghi, A. (n.d.). criminal procedure (1st ed.). Tehran: institute of legal studies and research.

Maki al Alami, \& Sheykh Abi Abdoillah Shamsoddin. (2006). Loma Dameshghiye, translated by Mohsen GHaravian, Ali Shirvani, Qom, Darolfekr, vol. 1.

Nuri Yashuluyi, J. (2008). set of rules and laws on currency and commodity smuggling. Tehran: Mizan publications.

Shabestani, S. M. (2001). the examples of health, medical and drug crimes in Iranian criminal law, Qom, second year, No. 3,4.

Shahcheraghi, S. A. (2001). legal and pseudo-legal nature of governmental reprimand, Qom, second year, summer and fall, No. 3 and 4.

Vatanpoor, A. (2008). smuggling and its effect on the economic security of the counry. Kargah journal, (3).

\section{Copyrights}

Copyright for this article is retained by the author(s), with first publication rights granted to the journal.

This is an open-access article distributed under the terms and conditions of the Creative Commons Attribution license (http://creativecommons.org/licenses/by/4.0/). 